\title{
Natural Language Understanding: Methodological Conceptualization
}

\section{Понимание естественного языка: методологическая концептуализация}

\author{
Vitalii Shymko \\ Dr. in Psychology, \\ Professor
}

\author{
Виталий Шимко \\ доктор психологических наук, \\ профессор
}

E-mail: shymko@,outlook.com orcid.org/0000-0003-4937-6976

\author{
Pereiaslav-Khmelnytskyi \\ Hryhorii Skovoroda State \\ Pedagogical University \\ $\bowtie$ 30, Sukhomlynskyi Str., \\ Pereiaslav-Khmelnytskyi, Kyiv Reg., \\ Ukraine, 08401
}

\begin{abstract}
ГВУЗ «Переяслав-
Хмельницкий государственный педагогический университет имени Григория Сковороды»» $\triangle$ ул. Сухомлинского, 30, г. Переяслав-Хмельницкий, Киевская обл., Украина, 08401
\end{abstract}

Original manuscript received September 04, 2018

Revised manuscript accepted March 10, 2019

\begin{abstract}
This article contains the results of a theoretical analysis of the phenomenon of natural language understanding (NLU), as a methodological problem. The combination of structural-ontological and informational-psychological approaches provided an opportunity to describe the subject matter field of $N L U$, as a composite function of the mind, which systemically combines the verbal and discursive structural layers. In particular, the idea of NLU is presented, on the one hand, as the relation between the discourse of a specific speech message and the meta-discourse of a language, in turn, activated by the need-motivational factors. On the other hand, it is conceptualized as a process with a specific structure of information metabolism, the study of which implies the necessity to differentiate the affective (emotional) and need-motivational
\end{abstract}


influences on the NLU, as well as to take into account their interaction. At the same time, the hypothesis about the influence of needs on NLU under the scenario similar to the pattern of Yerkes-Dodson is argued. And the theoretical conclusion that emotions fulfill the function of the operator of the structural features of the information metabolism of NLU is substantiated. Thus, depending on the modality of emotions in the process of $N L U$, it was proposed to distinguish two scenarios for the implementation of information metabolism - reduction and synthetic. The argument in favor of the conclusion about the productive and constitutive role of emotions in the process of NLU is also given.

Key words: computational psycholinguistics, natural language understanding, structural ontology, information metabolism, language consciousness, verbal intelligence, artificial intelligence, mind.

\section{Introduction}

Natural language understanding (NLU) is an interdisciplinary scientific problem located at the intersection of humanitarian, linguistic, cognitive, computer, medical and other areas of knowledge. Over the past few decades, a huge interest in this topic has manifested itself in the framework of research on artificial intelligence (AI), where NLU occupies the most important place in the list of so-called AI-complete problems in creating a strong AI or Artificial general intelligence (Wikipedia, 2019). Certain practical successes here are obvious and generally noticeable, at least by the example of the everyday prevalence of voice control technology of computer gadgets. However, the quality of these very technologies eloquently demonstrates that the essential problem of NLU is far from being resolved.

In our view, the appropriate prospects have less to do with the craftsmanship of computer algorithms, but with the development of new theoretical models of NLU. Such attempts are carried out within the framework of computational psycholinguistics, where the attention of modern researchers is mainly focused in the neurocognitive direction (Averbeck, Latham \& Pouget, 2006, Carandini \& Heeger, 2012, Crocker, 1996, Friederici, 2012, Giraud \& Poeppel, 2012, Hagoort, 2005, Hale, 2001, Harley, 2005, Huettig, 2015, Lewis, Vasishth \& Van Dyke, 2006, Martin, 2016, McElree, 2000, Viglioco, 2015, Vosse \& Kempen, 2000 et al.). 
However, another involuntary unifying feature of most NLU studies is the problem of defining the mind as an operator of the language in general and the subject (acting agent) of NLU in particular. Namely, this category or simply not represented explicitly and is present in the works intuitively. Or else it is reduced to one or another variety of the intelligent agent concept (Russell \& Norvig, 2010). As a consequence, there has been an accumulation of the amount of empirical data, without any certainty, regarding the prospects for their transformation into an unified theoretical concept. Is it possible to solve the problem of NLU without hypothesizing the concept of mind? The answer is obvious, because it is contained in the original idea of the NLU, as a function of the mind. Thus, there is a need for a meta-theory of the NLU, which takes into account the linguistic ontology of the mind and, at the same time, has a heuristic potential for computational psycholinguistics.

Such a meta-theory, in our opinion, is logical to form at the intersection of structural-ontological and informational-psychological views on language intelligence and information metabolism, respectively. The purpose of this article is the describe of the author's ideas about the subject matter field of the NLU problem, which are formed based on these approaches. The stated theoretical ideas are conceptualized by us within the framework of a look at the NLU in line with the descriptive methodology.

\section{Methods and techniques of the research}

The ideas about NLU given in this publication are based on the systemic description of the mind as an energy phenomenon that unfolds in a space-time environment and is accompanied by the archetypal structuring of neural impulses into cognitive structures (images). In the genesis of this phenomenon, we distinguish two stages - development and maturity. In the first stage system (mind) acquires verbal morphology on the background of needs differentiation. The second stage is characterized by a motivational context and a predominance of discursive morphology (Shymko, 2018a, 2018b).

The most significant structural and ontological components of the development and transformation of the material of the system are schematically summarized in Figure 1. Thus, segment 1 displays 
the basic level of the system, its starting preverbal architecture with neurocognitive properties. The stage of developmental is represented by a structural layer consisting of segments 2, 3 and 4 (dotted curve line). The stage of maturity covers the segments $-5,6,7,8$ and 9 (solid curve line). For detailed acquaintance with the features of the system deployment we refer the interested reader to the above authors publications. And here we confine ourselves to the emphasis on the fact that the genesis of the mind is associated with the formation of structural layers, each of which is characterized by a specific morphology. At the same time, the reaching of the system to a new level does not replace and does not cancel the activity of the previous layer but is built on above it. Thus, the mind functions as a complex multicomponent formation.

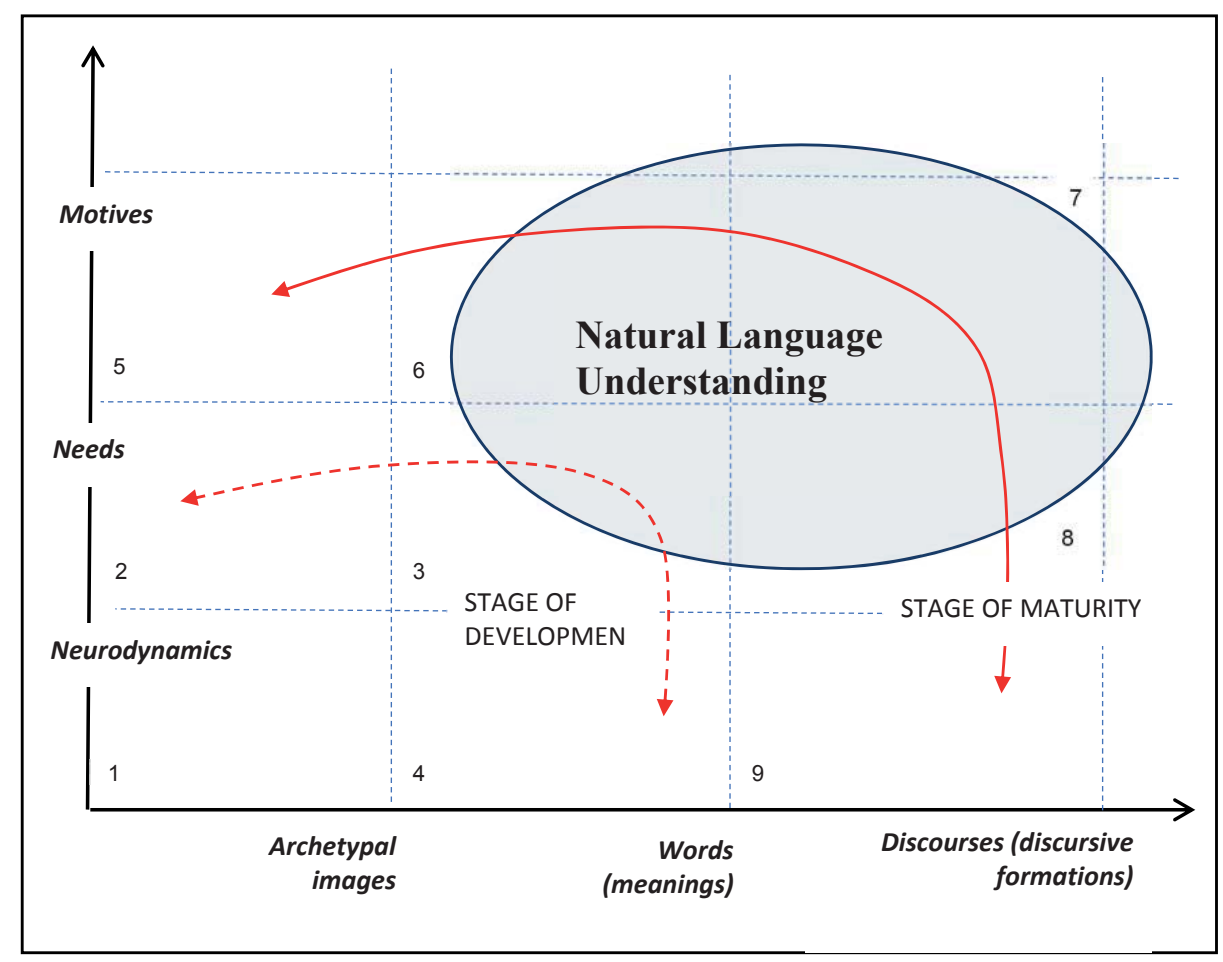

Fig. 1. Structural and ontological field of $N L U$

As we can see, NLU primarily covers the segments of the maturity stage, however, partially includes the stage of development (Fig. 1), 
during which the mind forms the ability to operate on meanings with the help of language tools (words). In turn, this ability is a necessary prerequisite for the emergence at the maturity stage of a system of such formation as - discourse. We understand the latter in line with the views of Foucault (1972), as the meaning of the dispersion of meanings. In our opinion, the discourse is constituted by the relation between the actual dispersion of meanings and the worldview of the subject $\left(D_{M}\right)$, as a global discursive formation (meta-discourse). At the same time, the structure of dispersion of discourse is transmitted from the cognitive plan into the affective sphere of the mind, as a result of which a hierarchy of significances of meanings is formed. This, along with the meaning, connects the discourse with the formation of sense (Shymko, 2018b).

We consider NLU as a composite function of the mature mind, which is organized and functions primarily discursively. At the same time, the grammatical structure of a language, in our opinion, also has a discursive organization and, by analogy with a worldview, represents a structural model of a global discursive formation (meta-discourse of a language). Thus, NLU appears as a relation between the discourse of a particular speech message or language construction $\left(D_{1}\right)$ and the metadiscourse of a language $\left(D_{L}\right)$. There are two important stipulations in the proposed look at NLU. Firstly, from the ontological point of view, language does not exist outside of the intelligent entity, that is, $\mathrm{D}_{\mathrm{L}}=$ $\mathrm{D}_{\mathrm{M}}$. Secondly, it is necessary to take into account the influence of the need-motivational factors, the expediency of which obviously follows from the structural and ontological localization of the NLU (Fig. 1).

Based on the results of our analysis (Shymko, 2018a, 2018b), we believe that such an impact on the NLU process arises on the structural layer of the system, which corresponds to the stage of development of the mind (segments 2, 3, 4 in Fig. 1). Namely, needs $(\mathrm{N})$ constellate a meta-discourse presented at this level by a set of verbal meanings. Their dispersion and, as a consequence, the emergence of the discursive mind morphology occurs in the next structural layer of the system (segments 5, 6, 7, 8, 9 in Fig. 1). Here, the interaction of needs with metadiscourse is characterized by them objectification and the formation of motives (M), which we understand in line with the views of Leontev (1978). At the same time, we note that the negative modality of the 
parameter $(-\mathrm{N})$ in the logical formulas proposed below indicates a dissatisfaction of needs.

$$
M=-N * D_{L}
$$

The integral $\int\left(-N * D_{L}\right)$ in formula 2 represents the simultaneous «accounting for» the needs and motives influence, and makes it possible to represent the PEU as the relation between the discourse of a specific speech message and the meta-discourse that is actualized by the current need-motivational configuration of the mind.

$$
N L U=\frac{D_{l}}{\int\left(-N * D_{L}\right)}
$$

On the other hand, when constructing the conceptualization of NLU, we compared the structural-ontological concept with the informational and psychological view on this problem. For this purpose, we used the approach of the information theory of emotions by Simonov (1991):

$$
E=-N\left(I_{n}-I_{a}\right)
$$

In this formula: $\mathrm{E}$ - emotion; - $\mathrm{N}$ is the activated need, $\mathrm{I}_{\mathrm{n}}$ is the necessary information and $I_{a}$ is the existing (available) information. Depending on the ratio of the necessary and existing information, the modality of emotional experience is determined. However, the heuristic potential of this equation goes far beyond the indication of the modality of emotions, since it contains the logic of informational metabolism and its connection with the sphere of needs and affects. Simonov's approach allows us to answer the question of WHAT exactly is happening in the process of NLU, and the structural-ontological view reveals the answer to the question HOW? The intersection of these research vectors allowed us to propose the methodological concept of the NLU, to the description of which we turn below.

\section{Results and Discussions}

The main difficulty of the presented theoretical analysis lies in the plane of consistency of the two approaches. The solution of such a problem in the field of descriptive methodology, in our opinion, can be 
carried out by drawing parallels based on the functionality of the object under study. In particular, we assumed that NLU, from a functional point of view, is identical to In. Namely, we considered the NLU in the context of the emerging need for the mind to solve the informational task of reconstructing the meanings from a speech message.

$$
N L U=I_{n}=I_{a}-\frac{E}{N}
$$

Continuing the logic of the functional parallels, we considered the parameter $\mathrm{I}_{\mathrm{a}}$, as an identical to the information that has been updated in the meta-discourse at each particular moment of the NLU.

$$
I_{a}=\int\left(-N * D_{L}\right)
$$

Thus, the NLU process takes the following schematic form:

$$
\frac{D_{l}}{\int\left(-N * D_{L}\right)}=\int\left(-N * D_{L}\right)-\frac{E}{N}
$$

This equation (formula 6) expresses the essence of our ideas about the subject matter field of the problem of the NLU, as well as about the key functional processes of the mind, as the acting agent of the NLU. The left part of the expression displays the structural ontology of NLU, which we discussed in detail above. Right - reveals the relevant information dynamics, consideration of the features of which we begin with an attempt to understand the parameter $\left(\frac{E}{N}\right)$.

«The relationship of emotions with needs can manifest itself in two ways - in accordance with the duality of the need itself, which, being felt by an individual in opposing him, means simultaneously his dependence on something and striving for it» (Rubinstein, 1999: 583).

Let's draw attention to the fact that in this quotation the object of need is «opposed» in relation to the subject. In terms of our consideration, such localization indicates not so much the need, but its objective equivalent, i.e. motive (formula 1). As already noted by us, the motive is constituted by the interaction of needs and meta-discourse (DL). This nuance in the Rubinstein position is important for us because it indirectly confirms the validity of the location of the parameter $(-\mathrm{N})$ in the denominator of formula 2.

«The relationship between emotions and needs is far from clear. Already in an animal that has only organic needs, the same 
phenomenon can have a different and even opposite - positive and negative -meaning due to the diversity of organic needs: satisfying one, it can go to the detriment of another. <...> Even less clearly is this relationship in a person. Human needs are not limited to organic needs only; he has a whole hierarchy of different needs, interests, attitudes» (Rubinstein, 1999: 584).

And in this case, the given point of view on $\left(\frac{E}{N}\right)$ as well corresponds to our position that the structure of the meanings dispersion in a discourse is transmitted into the affective sphere, which leads to the formation of significances of meanings, which are being experienced emotionally. The latter, in turn, interact with the need-motivational stimulation (Shymko, 2018b: 417). Thus, the understanding of information metabolism in the NLU process implies the necessity for differentiation of affective and need-motivational factors, as well as the consideration of their interaction.

Parametric evaluation of this interaction goes beyond the target scope of this conceptualization and requires a separate empirical study. However, there are some qualitative aspects of the influence of needs and emotions on NLU, which we would like to focus on in this work. Let's start with the needs factor, which detects the end-to-end presence in all components of the PEY formula. The presence of activated needs is a fundamental prerequisite for NLU. In other words, the NLU process involves a certain «frustration background», which has a dual influence on the NLU, based on well-known functions of needs.

On the one hand, the intensity of the need is directly proportional to the amount of actualized energy (recall that we consider the mind in the context of the energy paradigm of the natural sciences). On the other hand, the amount of energy needs is not necessarily relevant to the amount of information. So, frustration often has a focusing effect on the mind, narrowing its locus to meanings, that are associated with corresponding needs. At the same time, unrealized excess energy can be channeled using other mechanisms (for example, emotional experiences). We expect that the change in value $(-\mathrm{N})$ will affect $\int\left(-N * D_{L}\right)$ according to a scenario similar to the pattern of YerkesDodson (1908). As we see, the influence of needs on NLU is both quantitative and qualitative.

Emotions have the same important influence in the proposed NLU model, but according to a fundamentally different structural role. 
Namely, we are talking about the modality of $\left(\frac{E}{N}\right)$, which by default is negative (formula 6), since it expresses the dissatisfaction of the need. The need cannot be positive by definition, and when $\mathrm{N}=0$ (satisfied need), the formula does not make sense. If the emotional factor is positive, the equation retains its original form. However, in the case of a negative modality of emotions, summation appears in the right side of the formula instead of the subtraction. Thus, the modality of emotions serves as an operator of the information metabolism structure.

So, consider the qualitative differences that arise in the process of NLU with different values of emotions. When ( $E>0)$, the NLU is performed as the subtraction of a certain value from the current configuration of the meta-discourse. NLU has the character of reduction. The information that will still be obtained as a result of the NLU is already contained in the meta-discourse activated by the needs. Figuratively speaking, in the process of NLU, there is a «discarding of excess». We propose to denote such a variant of NLU as reduction scenario.

When $(\mathrm{E}<0)$, NLU implements informational metabolism by summation. Negative emotions lead to the addition of information not previously activated in the meta-discourse. NLU acquires a character of synthesis. In the process of NLU, an «addition of a new information» takes place. We suggest calling the corresponding variant of NLU synthetic scenario.

However, based on our formula, technically it is also possible that $(\mathrm{E}=0)$. In this case, our equation becomes truncated form: $\frac{D_{l}}{\int\left(-N * D_{L}\right)}=\int\left(-N * D_{L}\right)$. This means that as a result of the NLU, the information contained in the meta-discourse has not changed at all and remains identical to the previous state. Such a configuration is possible in a situation where, in the process of the NEP, for some reason, there was no dispersion of meanings and, as a result, no discourse was formed $\left(D_{1}=0\right)$. From the ontological point of view, in such a case it is impossible to speak about NLU per se. In our opinion, such a structural model can correspond to a primitive memory function used to match a perceived speech message with a preexisting set of language unit combinations. However, such a «simplification» is excluded by our understanding of the structural ontology of the mind, as an entropic energy system (Shymko, 2018a, 2018b). As we can see, the role of 
emotions in the NLU is not only productive, but also in terms of the specificity of the information metabolism - constitutive.

The stated aspect, in our opinion, is another argument in scientific discussions about how promising the development of exclusively cognitive models of NLU is. As we have shown, emotions act as an operator of the information metabolism structure of NLU. This, together with the nonlinearity of the interaction of emotions and needs, perhaps, hurdles the accessibility of the frontier known as the Turing test (1950). After all, the intuitive ability of the living mind to distinguish artificial speech is based on data obtained precisely in the process of NLU.

\section{Conclusions}

Summing up the material presented in this publication, we note the following most important components of the methodological conceptualization of the NLU. The combination of structural-ontological and informational-psychological approaches provided an opportunity to describe the subject matter field of NLU, as a composite function of the mind, which systemically combines the verbal and discursive structural layers. In particular, the idea of NLU is presented, on the one hand, as the relation between the discourse of a specific speech message and the meta-discourse of a language, in turn, activated by the needmotivational factors. On the other hand, it is conceptualized as a process with a specific structure of information metabolism, the study of which implies the necessity to differentiate the affective (emotional) and needmotivational influences on the NLU, as well as to take into account their interaction. At the same time, the hypothesis about the influence of needs on NLU under the scenario similar to the pattern of Yerkes-Dodson is argued. And the theoretical conclusion that emotions fulfill the function of the operator of the structural features of the information metabolism of NLU is substantiated. Thus, depending on the modality of emotions in the process of NLU, it was proposed to distinguish two scenarios for the implementation of information metabolism - reduction and synthetic. The argument in favor of the conclusion about the productive and constitutive role of emotions in the process of NLU is also given.

Speaking about the prospects for further research, we tend to divide them into two groups - theoretical and practical areas of study. Regarding the first group, we believe that further work on 
the construction of methodological conceptualization, which would encompass not only NLU, but also the problem of natural language processing (NLP) as a whole, including such components as speech synthesis, text generation, etc., is relevant. The solution of such a large-scale task is not conceived otherwise than in the context of work on a global scientific problem - the construction of a theoretical and methodological map of the conscious mind. With regards to the second group of studies, practical experiments aimed at verifying hypotheticaldeductive theories of language consciousness are of particular relevance. An example of one of these theories is this work. The proposed formulas are not mathematical and, moreover, statistical models of the corresponding phenomena, processes and facts. They are nothing more than a way to present actual logical concepts that describe the possible topography of the NLU subject matter field. The use of this way of presenting material is fully justified in view of the pioneering state of the area being studied and the absence of even an approximate map for traveling deeper into the psychology of linguistic consciousness. On the other hand, we hope that our calculations will serve as prototype methodological sketches for future testing and corresponding empirical corrections in the field of computational psycholinguistics.

\section{References}

Averbeck, B.B., Latham, P.E., \& Pouget, A. (2006). Neural correlations, population coding and computation. Nature Reviews Neuroscience, 7(5), 358-366. https:// doi.org/10.1038/nrn1888

Carandini, M., \& Heeger, D.J. (2012). Normalization as a canonical neural computation. Nature Reviews Neuroscience, 13(1), 51-62. https://doi.org/10.1038/nrn3136

Crocker, M.W. (1996). Computational Psycholinguistics an Interdisciplinary Approach to the Study of Language. Springer, Dordrecht.

Foucault, M. (1972). Archaeology of knowledge and the discourse on language. New York: Pantheon.

Friederici, A.D. (2012). The cortical language circuit: From auditory perception to sentence comprehension. Trends in Cognitive Sciences, 16(5), 262-268. https:// doi.org/10.1016/j.tics.2012.04.001

Giraud, A.-L., \& Poeppel, D. (2012). Cortical oscillations and speech processing: Emerging computational principles and operations. Nature Neuroscience, 15(4), 511-517. https://doi.org/10.1038/nn.3063

Hagoort, P. (2005). On broca, brain, and binding: A new framework. Trends in Cognitive Sciences, 9(9), 416-423. https://doi.org/10.1016/j.tics.2005.07.004

Hale, J. (2001). A probabilistic earley parser as a psycholinguistic model. Proceedings of the Second Meeting of the North American Chapter of the 
Association for Computational Linguistics on Language Technologies (pp. 1-8). Stroudsburg, PA: Association for Computational Linguistics. https://doi. org $/ 10.3115 / 1073336.1073357$

Harley, T.A. (2005). The Psychology of Language From Data to Theory (2nd ed.). Taylor \& Francis.

Huettig, F. (2015). Four central questions about prediction in language processing. Brain Research, 1626, 118-135. https://doi.org/10.1016/j.brainres.2015.02.014

Leontev, A.N. (1978). Activity, Consciousness, and Personality. Prentice-Hall https:// www.marxists.org/archive/leontev/works/1978/index.htm

Lewis, R.L., Vasishth, S., \& Van Dyke, J.A. (2006). Computational principles of working memory in sentence comprehension. Trends in Cognitive Sciences, 10(10), 447-454. https://doi.org/10.1016/j.tics.2006.08.007

Martin, A.E. (2016). Language processing as cue integration: Grounding the psychology of language in perception and neurophysiology. Frontiers in Psychology, 7, Article ID 120. https://doi.org/10.3389/fpsyg.2016.00120

McElree, B. (2000). Sentence comprehension is mediated by content-addressable memory structures. Journal of Psycholinguistic Research, 29(2), 111-123. https:// doi.org/10.1023/A:1005184709695

Rubinstein, S.L. (1999). Fundamentals of General Psychology. Russia: Piter Com.

Russell, S.J., \& Norvig, P. (2010). Artificial intelligence: a modern approach (3rd ed.). Upper Saddle River: Prentice Hall.

Shymko, V. (2018a). In Pursuit of the Functional Definition of a Mind: the Inevitability of the Language Ontology. Psycholinguistics, 23(1), 327-346. https://doi. org/10.5281/zenodo. 1211593

Shymko, V. (2018b). In Pursuit of the Functional Definition of a Mind: the Pivotal Role of a Discourse. Psycholinguistics, 24(1), 403-424. https://doi.org/10.31470/23091797-2018-24-1-403-424

Simonov, P.V. (1991). Motivated Brain a Neurophysiological Analysis of Human Behavior. Publisher: Routledge.

Turing, A. (1950). Computing Machinery and Intelligence (pp. 433-460).

Vigliocco, G. (2015). Psychology of Language: From the 20th to the 21st Century. 1st May. Observer. [Online]. [6 February 2019]. Available from https://www. psychologicalscience.org/observer

Vosse, T., \& Kempen, G. (2000). Syntactic structure assembly in human parsing: A computational model based on competitive inhibition and lexicalist grammar. Cognition, 75(2), 105-143. https://doi.org/10.1016/S0010-0277(00)00063-9

Wikipedia. (2019). Natural-language understanding. [Online]. [6 February 2019]. Available from https://en.wikipedia.org/wiki/Natural-language_understanding

Yerkes, R.M., \& Dodson, J.D. (1908). The relation of strength of stimulus to rapidity of habit-formation. Journal of Comparative Neurology and Psychology, 18(5), 459-482. https://doi.org/10.1002/cne.920180503

\section{АННОТАЦИЯ}

Данная статья содержит результаты теоретического анализа феномена понимания естественного языка (ПЕЯ), как методологической проблемы. Объединение структурно-онтологического и информационно-психологических подходов обеспечило возможность описать предметное поле ПЕЯ, как 
композитной функции разума, который системно объединяет вербальный и дискурсивный структурные слои. В частности, ПЕЯ представлено, с одной стороны, как отношение между дискурсом конкретного речевого сообщения и мета-дискурсом языка, в свою очередь, актуализированного потребностномотивационными фракторами. С другой стороны, ПЕЯ концептуализировано, как процесс со специфической структурой информационного метаболизма, исследование которого предполагает необходимость дифференциации арфективного и интенционального влияний на ПЕЯ, а также учета их соотношения. При этом, аргументирована гипотеза о влиянии потребностей на ПЕЯ по сценарию, аналогичному закономерности Йеркса-Додсона. Также обоснован теоретический вывод о том, что эмоции выполняют функцию оператора структурных особенностей информационного метаболизма ПЕЯ. Так, в зависимости от модальности эмоций в процессе ПЕЯ, предложено выделять два сценария осуществления информационного метаболизма редукционный и синтетический. Приведена аргументация в пользу вывода о продуктивной и конституирующей роли эмоций в процессе ПЕЯ.

Ключевые слова: вычислительная психолингвистика, понимание естественного языка, структурная онтология, информационный метаболизм, языковое сознание, вербальный интеллект, искусственный интеллект, разум.

\section{Шимко Віталій. Розуміння природної мови: методологічна концептуалізація}

\section{АНОТАЦІЯ}

у цій статті викладено результати теоретичного аналізу феномена розуміння природної мови (РПМ), як методологічної проблеми. Об'єднання структурно-онтологічного та інформаційно-психологічних підходів забезпечило можливість описати предметне поле РПМ, як композитної функції розуму, який системно об'єднує вербальний і дискурсивний структурні шари. Зокрема, РПМ представлено, з одного боку, як відношення між дискурсом конкретного мовного повідомлення і мета-дискурсом мови, в свою чергу, актуалізованого потрібнісно-мотиваційними чинниками. 3 іншого боку, РПМ концептуалізовано, як процес зі специфічною структурою інфрормаційного метаболізму, дослідження якого передбачає необхідність диференціації арективного та інтенційного впливів на РПМ, а також врахування їх співвідношення. При цьому, аргументована гіпотеза про вплив потреб на РПМ за сценарієм, аналогічним закономірності Йєркса-Додсона. Також обгрунтований теоретичний висновок про те, що емоції виконують функцію оператора структурних особливостей інформаційного метаболізму РПМ. Так, в залежності від модальності емоцій в процесі РПМ, запропоновано виділяти два сценарії здійснення інформаційного метаболізму - редукційний і синтетичний. Наведено аргументацію на користь висновку щодо продуктивної та конституційної ролі емоцій в процесі РПМ.

Ключові слова: обчислювальна психолінгвістика, розуміння природної мови, структурна онтологія, інформаційний метаболізм, мовна свідомість, вербальний інтелект, штучний інтелект, розум. 